\title{
Thinking better about rural wealth creation and retention
}

\author{
Review by David L. Kay* \\ Cornell University
}

Review of Wealth Creation: A New Framework for Rural Economic and Community Development, by Shanna E. Ratner. (2020). Routledge. Available as ebook, hardcover, and paperback; 174 pages. Publisher's website:

https://www.routledge.com/Wealth-Creation-A-New-

Framework-for-Rural-Economic-and-CommunityDevelopment/Ratner/p/book/9780367257422

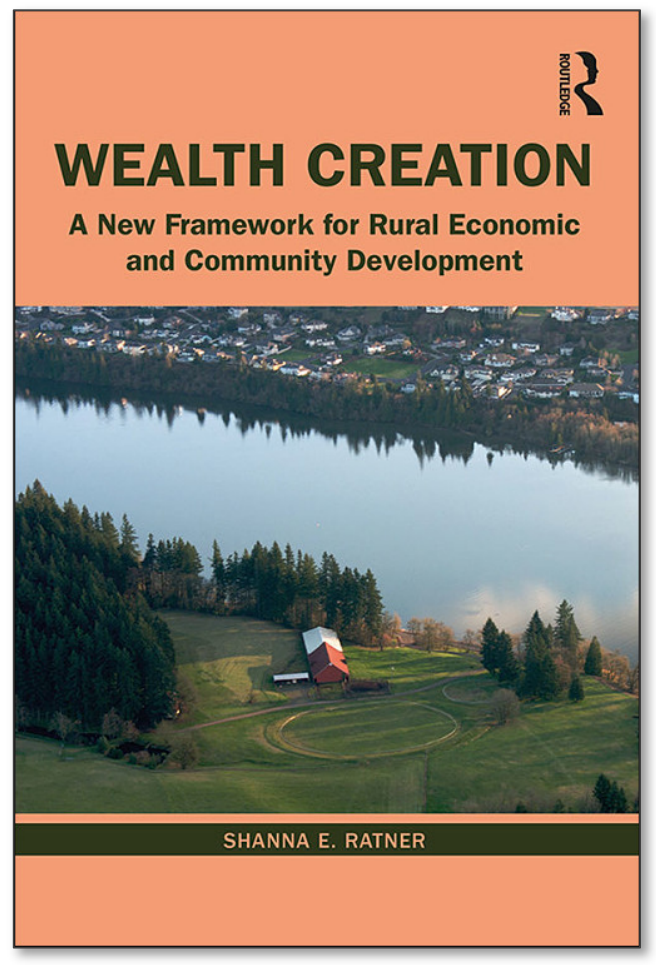

Submitted January 28, 2021 / Revised February 2, 2021 / Published online March 25, 2021

Citation: Kay, D. L. (2021). Thinking better about rural wealth creation and retention

[Book review]. Journal of Agriculture, Food Systems, and Community Development, 10(2), 595-598. https://doi.org/10.5304/jafscd.2021.102.046

Copyright (C) 2021 by the Author. Published by the Lyson Center for Civic Agriculture and Food Systems. Open access under CC-BY license.

$\mathrm{F}$ or some decades now, the practices of economic and community development have increasingly intertwined. This has largely involved a rebalancing of the economic and community portions of the mix to give increasing prominence to the community side of the ledger. In their decadeand-a-half-old article, Rethinking Community Economic Development, Shaffer, Deller, and Marcouiller (2006)

* David Kay, Senior Extension Associate, Department of Global Development, College of Agriculture and Life Sciences; Fellow, Atkinson Center for Sustainability; Affiliate, Program on Infrastructure Policy, Cornell University; 275E Warren Hall; Ithaca, NY 14853 USA; +1-607-255-2123; dlk2@,cornell.edu illustrated this in their classification of successive waves of dominant community economic development (CED) theory and practice: export base, business retention and expansion, collaboration and partnership driven, and cluster development.

Shanna Ratner's 2020 book Wealth Creation: $A$ New Framework for Rural Economic and Community Development comes from one of the leading developers and practitioners of a fifth-wave approach that is beginning to lay a legitimate claim to the respect of academics, professionals, and community members alike. In 158 pages, Ratner's slim and accessible volume does an admirable job of summarizing a synthetic approach that is both 
informed by theory and steeped in decades of participant-observation and learning-by-doing. The author, often addressing the reader as "you," as if in the training workshops she has frequently provided, explicitly aims at writing for those with few degrees of separation from CED practice: "policy makers, practitioners in economic and community development, teachers, students [including undergraduates, I would specify], financers and funders..." (p. viii).

Ratner draws upon a heterogeneous array of applied rural CED and systems research, but typically to support a point in her narrative arc rather than in a more muscular effort to prove the point. The "WealthWorks" approach, as described in the book, has enough of a track record to offer a trove of success stories, and the author generously interleaves her book with insights garnered from case studies, especially those from the Ford Foundation's eight-year experiments with the approach in Central Appalachia, the Deep South, and the Lower Rio Grande regions of rural America. Readers of this journal will also appreciate that while the phrase "food systems" is absent from the Wealth Creation index, the book draws on the WealthWorks focus in these regions on food system and forest products, along with initiatives in the housing, energy, and finance sectors.

I would also remark here that while both the "rural" and the "local" figure extensively and with a strongly positive valence in Ratner's book and professional history, her centering of the importance of scale underscores her pragmatic commitment to regionalism and her recognition of the significance of globalization, along with her misgivings about autarky. In fact, Ratner's primary allegiance is to forging connections that serve to overcome systemic inequities, as encapsulated in her assertion that, "Economically marginalized places and people will stay poor unless they are connected to larger economies" (p. 5). Ratner is a Donella Meadows Leadership Fellow, and that tradition of systems thinking offers a thread that binds together the different strands of the book.

As heralded by the logical flow of the book's chapter titles, a small number of big concepts are arranged to create the framework that defines the distinctive approach to development presented in Wealth Creation. Some among the 10 chapters mapping the territory Ratner will survey highlight her central themes: What is/are Wealth? Wealth Creation Value Chains? How do ownership and control change the game? What does it mean to be demand driven? Other chapters dissect the roles of scale, technology, investors, impact measurement, and value chain coordinators in wealth creation. Many of these are worthy of commentary longer than is possible here, and the readers will appreciate engaging with the text themselves. However, I want to highlight with approval the emphasis given to the "critical roles of wealth creation value chain coordinators and coaches" (p. 138). Ratner both recognizes and advocates that fully equipped organizations and individuals with all the requisite attributes are essential to sustainable development and systemic change, while acknowledging they are scarce. Her experience-based reassurance is that the capacity to grow into these roles is inherent in many local and regional organizations and can emerge if they are offered the right kind of "training, coaching, and support" (p. 145).

Overarching all other concepts marshalled by Ratner is her definition of wealth and its significance in "wealth creation value chains." Unlike conventional chains that measure the value added at each stage of production in narrow market metrics, wealth creation value chains incorporate the "full range of values consumers want to support" (p. 29). In practice, WealthWorks adapts the "community capitals" precepts developed in the 2000s (Emery \& Flora, 2006) which appropriated narrower economistic conceptualizations of capital and applied them to a broader array of market and nonmarket assets or capitals (social, natural, etc.) that support CED. Importantly, this enables the deployment of a "wealth matrix" to draw attention to and steer accounting toward the effects of investments in multiple stocks of capital, each of which supports community and individual wellbeing, and perhaps most crucially draws attention to synergies and trade-offs between capitals. Ratner's adaptation slightly redefines some forms of capital and adds an eighth ("intellectual" capital), arguing that "investing in intellectual, individual and social capital ... has proven to be the starting 
point for wealth creation in the poorest areas of rural America" (p. 11).

Accepting an inclusive definition of wealth leads in a straight line to the need for better wealth measurement, "never a simple quantitative process" (p. 132). The chapter on measurement, in harmony with the overall WealthWorks approach, proposes guidelines and considerations for measurement of each form of capital rather than offering a list of decontextualized "correct" or "best" measures. Ratner's advocacy for measurement emphasizes not just the accountability that measurement enables, but also its contributions to learning and improvement.

Wealth Creation is full of gestures of boundless ambition, but all are ultimately grounded in an earned pragmatism. An example of the ambition from an apt musing in the preface: "What would happen if we could reinvent capitalism so the invisible hand becomes visible?" (p. viii). In response to her own question, Ratner makes a compelling if challenging case for a thoroughgoing decommodification of market relationships, coupled with an argument for the acceptance of a need for an even more thoroughgoing understanding of (potential) market demand. She aims broadly to "transform the way we think and approach our world and to produce positive changes at meaningful scale" (p. 25). But pragmatism infuses her concluding chapter: "Transforming market relationships cannot happen without building actual relationships between people. ... WealthWorks is not a silver bullet; it is hard work without guarantees" (p. 157).

As is perhaps inevitable in a brief book of this nature, the reader may sometimes feel that certain ideas and assertions are too scantily clad to be as authoritative or set in context as they might have been in a longer work. What wisdom have WealthWorks practitioners gained that is shared, or not, with practitioners of another increasingly influential approach to systems change, namely "collective impact" (see Hoey, Colasanti, Pirog, \&
Fink Shapiro, 2017), for example in comparing the roles of "value chain coordinators" and "backbone organizations"? How should the reader think about the lack of explicit attention to what is known about "entrepreneurship," whether private-sector or social? What is the relationship between WealthWorks and the Rural Wealth Creation approach that for some years now has been elevated, adopted, and evaluated by the U.S. Department of Agriculture (Pender, Marré, \& Reeder, 2012)? Does the book's worthwhile and important emphasis on measurement of capital stocks, and on changing "mindsets" in order to make "the larger system visible" (and more), demand too much investment in what some might label "capacity building" to make WealthWorks itself scalable? In other words, is the approach too demanding to be institutionalized and routinized, or might it lend itself to being widely reproducible in practice?

During Shaffer et al.'s review of leading CED approaches up to the turn of the last century, they raised into prominence two essential CED tasks threading through all: understanding the full range of choices available and engaging collaborators in building a long-term strategy. These tasks involve exceptional openness to new ideas and new relationships. Each of the tasks, too often approached casually or taken for granted, requires motivation, persistence, adaptability, communication, and an unadulterated commitment to hard work. The wealth creation framework advocated for in Ratner's book, informed as it is by a community development philosophy, does not offer a cut-anddried recipe for CED success. However, as emphasized in Ratner's title, it does offer a valuable framework for those involved in complex development systems. Wealth Creation can guide toward success those individuals and organizations working for better, more equitable, and more sustainable personal and community futures—so long as they are prepared to actively embrace the prospect of inevitable challenges and are imbued with a knack for learning by doing.

\section{References}

Emery, M., \& Flora, C. (2006). Spiraling-up: Mapping community transformation with Community Capitals Framework. Community Development, 37(1), 19-35. https://doi.org/10.1080/15575330609490152 
Hoey, L., Colasanti, K., Pirog, R., \& Fink Shapiro, L. (2017). Implementing collective impact for food systems change: Reflections and adaptations from Michigan. Journal of Agriculture, Food Systems, and Community Development, 7(2), 101-115. https://doi.org/10.5304/jafscd.2017.072.014

Pender, J., Marré, A., \& Reeder, R. (2012). Rural wealth creation: Concepts, strategies, and measures (Report No. ERR-131). U.S. Department of Agriculture, Economic Research Service. https://doi.org/10.2139/ssrn.2027084

Shaffer, R., Deller, S., \& Marcouiller, D. (2006). Rethinking community economic development. Economic Development Quarterly, 20(1), 59-74. https://doi.org/10.1177/0891242405283106 